\title{
Comparative Expression of P53 and Survivin Proteins in Phenylhydrazine-Induced Colon Cancer of Rats and the Role of Electromagnetic Field and Broccoli Extract
}

\author{
Aziz Awaad ( $\nabla$ aawaad@science.sohag.edu.eg ) \\ Sohag University Faculty of Science, Department of Zoology \\ Mohamed A. Adly \\ Sohag University Faculty of Science, Department of Zoology \\ Medhat A. Abd ellatef \\ Sohag University Faculty of Science, Department of Physics \\ Moshira M. Foad \\ Sohag University Faculty of Science, Department of Zoology
}

Keywords:

Posted Date: June 1st, 2021

DOl: https://doi.org/10.21203/rs.3.rs-531992/v1

License: (a) (1) This work is licensed under a Creative Commons Attribution 4.0 International License.

Read Full License 


\section{Abstract}

The authors have requested that this preprint be removed from Research Square. 